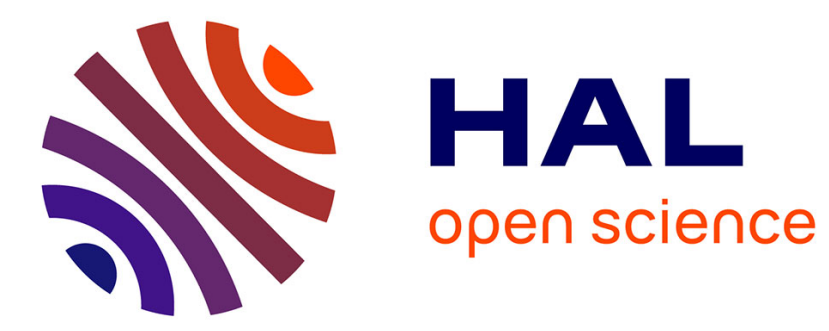

\title{
Thermal decomposition of lead white for radiocarbon dating of paintings
}

Lucile Beck, Cyrielle Messager, Stéphanie Coelho, Ingrid Caffy, Emmanuelle

Delqué-Količ, Marion Perron, Solène Mussard, Jean-Pascal Dumoulin, Christophe Moreau, Victor Gonzalez, et al.

\section{To cite this version:}

Lucile Beck, Cyrielle Messager, Stéphanie Coelho, Ingrid Caffy, Emmanuelle Delqué-Količ, et al.. Thermal decomposition of lead white for radiocarbon dating of paintings. Radiocarbon, 2019, 61, pp.1345-1356. 10.1017/RDC.2019.64 . cea-02183134

\section{HAL Id: cea-02183134 https://hal-cea.archives-ouvertes.fr/cea-02183134}

Submitted on 15 Jun 2021

HAL is a multi-disciplinary open access archive for the deposit and dissemination of scientific research documents, whether they are published or not. The documents may come from teaching and research institutions in France or abroad, or from public or private research centers.
L'archive ouverte pluridisciplinaire $\mathbf{H A L}$, est destinée au dépôt et à la diffusion de documents scientifiques de niveau recherche, publiés ou non, émanant des établissements d'enseignement et de recherche français ou étrangers, des laboratoires publics ou privés. 


\title{
THERMAL DECOMPOSITION OF LEAD WHITE FOR RADIOCARBON DATING OF PAINTINGS
}

\author{
Lucile Beck $^{1} \cdot$ Cyrielle Messager $^{1} \cdot$ Stéphanie Coelho $^{1} \cdot$ Ingrid Caffy $^{1} \cdot$ Emmanuelle Delqué- $^{-}$ \\ Količ $^{1} \cdot$ Marion Perron $^{1} \cdot$ Solène Mussard $^{1} \cdot$ Jean-Pascal Dumoulin $^{1} \cdot$ Christophe Moreau $^{1} \cdot$

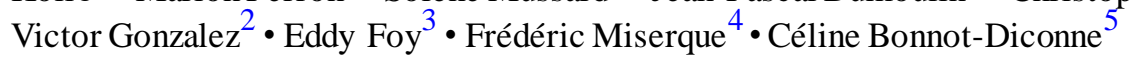 \\ ${ }^{1}$ Laboratoire de Mesure du Carbone 14 (LMC14), LSCE/IPSL, CEA-CNRS-UVSQ, Université Paris-Saclay, F-91191 Gif- \\ sur-Yvette, France \\ ${ }^{2}$ Department of Materials Science and Engineering, Delft University of Technology, Mekelweg 5, 2628 CD Delft, The \\ Netherlands \\ ${ }^{3}$ LAPA-IRAMAT, NIMBE, CEA, CNRS, Université Paris-Saclay, CEA Saclay, 91191 Gif-sur-Yvette, France \\ ${ }^{4}$ DEN Service de la Corrosion et du Comportement des Matériaux dans leur Environnement (SCCME), CEA, Université \\ Paris-Saclay, F-91191, Gif-sur-Yvette, France \\ $5_{2}$ CRC - Centre de Conservation et de Restauration du Cuir, Activillage - Centr'ALP, 235 rue de Corporat, 38430 \\ Moirans, France
}

\begin{abstract}
Lead carbonates were used as cosmetic and pigment since Antiquity. The pigment, known as lead white, was generally composed of cerussite and hydrocerussite. Unlike most ancient pigments, lead white was obtained by a synthetic route involving metallic lead, vinegar and organic matter. Fermentation of organic matter produces heat and $\mathrm{CO} 2$ emission, leading to the formation of carbonates. As lead white is formed by trapping $\mathrm{CO}_{2}$, radiocarbon $\left({ }^{14} \mathrm{C}\right)$ dating can thus be considered. We have developed a protocol to prepare lead white. We selected modern pigments for the experiment implementation and ancient cosmetic and paintings for dating. After characterization of the samples by XRD, thermal decomposition of cerussite at various temperatures was explored in order to select the appropriate conditions for painting samples. $\mathrm{CO} 2$ extraction yield, SEM and XPS were used to characterize the process. Thermal decomposition at $400^{\circ} \mathrm{C}$ was successfully applied to mixtures of lead white with other paint components (oil as binder, calcite as filler/extender) and to historical samples. We obtained radiocarbon measurements in agreement with the expected dates, demonstrating that thermal decomposition at $400^{\circ} \mathrm{C}$ is efficient for a selective decomposition of lead white and that paintings can be directly ${ }^{14} \mathrm{C}$-dated by dating lead white pigment.
\end{abstract}

KEYWORDS: cerussite, gilt leather, lead white, painting, radiocarbon dating, thermal decomposition.

\section{INTRODUCTION}

Lead carbonates were one of the major materials used in art and archaeology from Antiquity to the 19 th century. Various phases of lead carbonate were used as ingredients in cosmetics and paints. Cerussite $\left(\mathrm{PbCO}_{3}\right)$ and phosgenite $\left(\mathrm{Pb}_{2} \mathrm{Cl}_{2} \mathrm{CO}_{3}\right)$ were employed in cosmetic powders by ancient Egyptians, Greeks and Romans (Lucas 1930; Walter et al. 1999; Welcomme et al. 2006; Martinetto et al. 2001; Katsaros et al. 2010). Cerussite and hydrocerussite $\left(\mathrm{Pb}_{3}\left(\mathrm{CO}_{3}\right)_{2}(\mathrm{OH})_{2}\right)$ were the compounds of lead white (Welcomme et al. 2007; de Viguerie et al. 2009; Beck et al. 2010; Gonzalez et al. 2017a), which was the most widely used white pigment until its poisonous effect restricted its manufacture in the 20th century (Gettens et al. 1993). Lead carbonates exist as natural minerals and as manufactured compounds. The production of cerussite is described in several historical written sources in Antiquity (Theophrasus, Dioscorides, Pliny the Elder) and from the Renaissance to the 19th century (Stols-Witlox 2014). The historical method of preparing lead white pigment is based on the process generally known as the "stack process" where metallic lead is exposed to vapors of acetic acid and carbon dioxide (Stols-Witlox 2014; Gonzalez et al. 2017b). Lead corrodes, forming lead acetate and lead carbonates. At the end of the process, the surface of the metal is covered with flakes of lead white. From Antiquity to the 19th century, the acetic acid was in the form of vinegar

\footnotetext{
*Corresponding author. Email: lucile.beck@cea.fr.
} 
and carbon dioxide gas came from the fermentation of natural organic matter such as horse manure or tanner bark (Pulsifer 1888; Stols-Witlox 2014). Considering this method, we recently demonstrated that radiocarbon $\left({ }^{14} \mathrm{C}\right)$ was incorporated during the synthesis and we successfully dated lead carbonates in ancient cosmetics (Beck et al. 2018). Here, we aim to extend the method to paintings as also proposed by Hendriks et al. (2019) in a recent publication ${ }^{1}$. Dating lead white pigment can be an alternative or a complement to ${ }^{14} \mathrm{C}$ measurements on canvas, wood or binder for their authentication (Caforio et al. 2013; Fedi et al. 2014; Hendriks et al. 2016, 2018; Brock et al. 2018).

The preparation of carbonate samples for ${ }^{14} \mathrm{C}$ analysis is usually carried out by acid hydrolysis. $\mathrm{CO}_{2}$ is recovered from carbonate samples using pure phosphoric acid $\left(\mathrm{H}_{3} \mathrm{PO}_{4}\right)$. However, in the case of a mixture of carbonates, typically the mixture of lead white with chalk that is very common in paintings (Stols-Witlox 2011), hydrolysis will extract $\mathrm{CO}_{2}$ from all carbonates. As chalk contains dead carbon, we anticipated that this process would not be suitable for real samples and therefore explored another approach based on thermal decomposition. Carbonates undergo thermal decomposition to give the metal oxide and carbon dioxide gas (Beck 1950).

Differential thermal analysis of cerussite and hydrocerussite has been extensively studied in the past in various conditions such as $\mathrm{CO}_{2}$ and inert atmospheres (Warne and Bayliss 1962; Ball and Casson 1975; Ciomartan et al. 1996). Thermal decomposition produces the evolution of $\mathrm{CO}_{2}$, the decomposition product being either the corresponding oxide or a basic carbonate, the latter decomposing with further evolution of $\mathrm{CO}_{2}$ as the temperature is raised. In order to determine the appropriate conditions for the preparation of lead white for ${ }^{14} \mathrm{C}$ dating, we investigated the thermal decomposition of $\mathrm{PbCO}_{3}$ with two goals in mind: optimizing the $\mathrm{CO}_{2}$ production yield and collecting $\mathrm{CO}_{2}$ from lead carbonate only. $\mathrm{CO}_{2}$ extraction yield, scanning electron microscopy (SEM) and x-ray photoelectron spectroscopy (XPS) were used to characterize the process. This procedure was then applied to mixtures of lead white with other paint components (oil as binder, calcite as filler/extender) and to historical samples: a Greek cosmetic from the Louvre Museum and two painted gilt leather wall hangings from a private collection.

\section{MATERIALS AND METHOD}

\section{Sample Description and Material Analysis}

Modern materials were first used to explore the experimental conditions for the preparation of lead white and then historical samples were prepared and dated. A commercial lead white pigment was obtained from a supplier who reproduces or adapts historical processes. For this study, two types of commercial products were available. For the thermal decomposition experiments, we used a lead white pigment produced according to the historical process, slightly modified: the carbon dioxide gas was provided by the fermentation of sugar and yeast dissolved in water (sample MM). According to the supplier, this method makes it easier to control the amount of $\mathrm{CO}_{2}$ and to produce a homogenous pigment structure. White flakes were collected, crumbled and milled with water to obtain a fine powder. Then the pigment was washed several times and air dried. X-ray diffraction showed that the lead white powder produced in that condition is composed of pure cerussite $\left(\mathrm{PbCO}_{3}\right)$. Mixtures of $\mathrm{MM}$ with calcite ( sample $\left.\mathrm{MM}+\mathrm{C}\right)$ or

\footnotetext{
1This article was submitted a few days before the publication of Hendriks et al. (2019).
} 
with linseed oil (sample $\mathrm{MM}+\mathrm{O}$ ) were also thermally studied. The second type of lead white was a modern reproduction of the historical stack process using horse manure. This pigment was made for restoration purposes in 2016 and was used in this study as a test sample (sample MH). X-ray diffraction showed that this lead white powder is composed of cerussite $\left(\mathrm{PbCO}_{3}\right)$ and hydrocerussite $\left(\mathrm{Pb}_{3}\left(\mathrm{CO}_{3}\right)_{2}(\mathrm{OH})_{2}\right)$ in similar amounts. To further validate the method, three historical samples were prepared and dated: one Greek cosmetic powder (GC) composed of cerussite and dated from the 4th-3rd centuries BC (Hasselin Rous and Huguenot 2017) and two paint samples (GL1 and GL2) taken from two gilt leathers used as decorative wall coverings between the 17th and the 18th centuries (Bonnot-Diconne et al. 2014). The description of the samples and the method used for their characterization are reported in Table 1.

\section{Sample Preparation}

Lead white preparation for ${ }^{14} \mathrm{C}$ dating was investigated by studying the thermal decomposition of sample MM composed of cerussite. Samples were heated at different temperatures (from 200 to $800^{\circ} \mathrm{C}$ ) on a manual vacuum line (Figure 1). For each temperature, 20-25 mg of lead white was decomposed in vacuum $\left(5 \times 10^{-6}\right.$ mbar $)$ for 1 or $2 \mathrm{hr}$, producing carbon dioxide and water. $\mathrm{CO}_{2}$ was separated from $\mathrm{H}_{2} \mathrm{O}$ using a dry ice/alcohol trap $\left(-78^{\circ} \mathrm{C}\right)$ and the pressure of each $\mathrm{CO}_{2}$ sample was measured to determine the extracted carbon content (Dumoulin et al. 2017). For each temperature, the total released $\mathrm{CO}_{2}$ was collected in a Pyrex tube sealed after collecting. Residues of the decomposition were preserved for their characterization by SEM (see Supplementary material) and XPS. The XPS device was a VG ESCALAB 220i XL spectrometer with a Al-Ka Xray source $(1486.6 \mathrm{eV})$.

The same procedure was applied to mixed carbonates containing $25 \mathrm{mg}$ of lead white $\left(\mathrm{PbCO}_{3}\right)$ and $10 \mathrm{mg}$ of $\mathrm{CaCO}_{3}$ (sample $\mathrm{MM}+\mathrm{C}$ ) and to a paint prepared in the laboratory with lead white and linseed oil (sample $\mathrm{MM}+\mathrm{O}$ ). For the test $(\mathrm{MH})$ and the historical samples, the decomposition was carried out at $400^{\circ} \mathrm{C}$, according to the results obtained from the preceding experiments and presented in the next section.

As support for the paintings, leather samples were also dated for comparison. They were prepared using the standard acid-base-acid method $\left(0.5 \mathrm{M} \mathrm{HCl}\right.$ at $80^{\circ} \mathrm{C}, 1 \mathrm{hr} / 0.1 \mathrm{M} \mathrm{NaOH}$ at $80^{\circ} \mathrm{C}, 1 \mathrm{hr} / 0.5$ $\mathrm{M} \mathrm{HCl}$ at $80^{\circ} \mathrm{C}, 1 \mathrm{hr}$ ), rinsed with ultra-pure water until neutral $\mathrm{pH}$ and then dried under vacuum overnight $\left(60^{\circ} \mathrm{C}, 0.1 \mathrm{mbar}\right) . \mathrm{CO}_{2}$ was obtained by combustion $\left(5 \mathrm{hr}, 850^{\circ} \mathrm{C}\right)$ in a quartz sealed tube with an excess of $\mathrm{CuO}\left(400-500 \mathrm{mg}\right.$ ) and a 1-cm $\mathrm{Ag}$ wire. $\mathrm{CO}_{2}$ was finally dried and collected on a semi-automated rig (Dumoulin et al. 2017).

$\mathrm{CO}_{2}$ of all the samples was then reduced to graphite with hydrogen over iron catalyst. ${ }^{14} \mathrm{C}$ measurements were performed by accelerator mass spectrometry (AMS) using the LMC14/ ARTEMIS facility (Moreau et al. 2013). ${ }^{14} \mathrm{C}$ ages were calculated using the Mook and van der Plicht (1999) recommendations and calibrated using OxCal v4.2 (Bronk Ramsey et al. 2013) and the IntCal13 atmospheric calibration curve (Reimer et al. 2013) for past ages and CaliBomb and the Levin curve (Levin and Kromer 2004) for pMC.

\section{RESULTS}

The results are presented in two sections. The first section deals with the development of the sample preparation for pure pigment, mixed pigments (lead white and calcite), paint, and 
Table 1 Lead white materials and analytical methods used in this study. Cerussite $=\mathrm{PbCO}_{3}$; hydrocerussite $=\mathrm{Pb}_{3}\left(\mathrm{CO}_{3}\right)_{2}\left(\mathrm{OH}_{2}\right.$; $\mathrm{calcite}=\mathrm{CaCO} 3$; $\mathrm{ThD}=$ thermal decomposition; XRD = x-ray diffraction; $\mathrm{SEM}=$ scanning electron microscopy; XPS = x-ray photoelectron spectroscopy; $(*)$ Hasselin Rous and Huguenot (2017).

\begin{tabular}{|c|c|c|c|c|c|c|c|c|c|}
\hline Label & Material & Sample information & $\begin{array}{l}\text { Date of } \\
\text { production or } \\
\text { expected age }\end{array}$ & $\begin{array}{l}\text { Composition } \\
\text { (main } \\
\text { components) }\end{array}$ & $\begin{array}{l}\mathrm{ThD} \text { from } \\
200^{\circ} \mathrm{C} \text { to } \\
800^{\circ} \mathrm{C}\end{array}$ & $\begin{array}{l}\mathrm{ThD} \text { at } \\
400^{\circ} \mathrm{C}\end{array}$ & XRD & SEM & $\begin{array}{l}\text { XPS on } \\
\text { residues }\end{array}$ \\
\hline MM & $\begin{array}{l}\text { Lead white } \\
\text { pigment }\end{array}$ & $\begin{array}{l}\text { Modified historical } \\
\text { process }\end{array}$ & End of 2015 & Cerussite & $\mathrm{x}$ & $\mathrm{x}$ & $\mathrm{x}$ & $\mathrm{x}$ & $\mathrm{x}$ \\
\hline $\mathrm{MM}+\mathrm{C}$ & $\begin{array}{l}\text { Lead white } \\
\text { pigment and } \\
\text { calcite } \\
\text { powder }\end{array}$ & $\begin{array}{l}\text { Mixture of MM with } \\
\text { calcite }\end{array}$ & Modern & $\begin{array}{l}\text { Cerussite and } \\
\text { calcite }\end{array}$ & $\mathrm{x}$ & $\mathrm{x}$ & & & \\
\hline $\mathrm{MM}+\mathrm{O}$ & Paint & $\begin{array}{l}\text { Mixture of MM with } \\
\text { binder }\end{array}$ & Modern & $\begin{array}{l}\text { Cerussite and } \\
\text { linseed oil }\end{array}$ & $\mathrm{x}$ & & & & \\
\hline MH & $\begin{array}{l}\text { Lead white } \\
\text { pigment }\end{array}$ & $\begin{array}{l}\text { Reproduction of the } \\
\text { historical stack process }\end{array}$ & 2016 & $\begin{array}{l}\text { Cerussite and } \\
\text { hydrocerussite }\end{array}$ & & $\mathrm{x}$ & $\mathrm{x}$ & & \\
\hline GC & $\begin{array}{l}\text { Compact } \\
\text { powder }\end{array}$ & Greek cosmetic & 4th-3rd c. BC & Cerussite & & $\mathrm{x}$ & $\mathrm{x}(*)$ & & \\
\hline GL1 & $\begin{array}{l}\text { Lead white } \\
\text { paint layer }\end{array}$ & Painting on gilt leather 1 & $\begin{array}{l}\text { Second half of } \\
\text { the } 17 \text { th century }\end{array}$ & Hydrocerussite & & $\mathrm{x}$ & $\mathrm{x}$ & $\mathrm{x}$ & \\
\hline GL2 & $\begin{array}{l}\text { Lead white } \\
\text { paint layer }\end{array}$ & Painting on gilt leather 2 & Before 1736 & Hydrocerussite & & $\mathrm{x}$ & $\mathrm{x}$ & $\mathrm{x}$ & \\
\hline
\end{tabular}




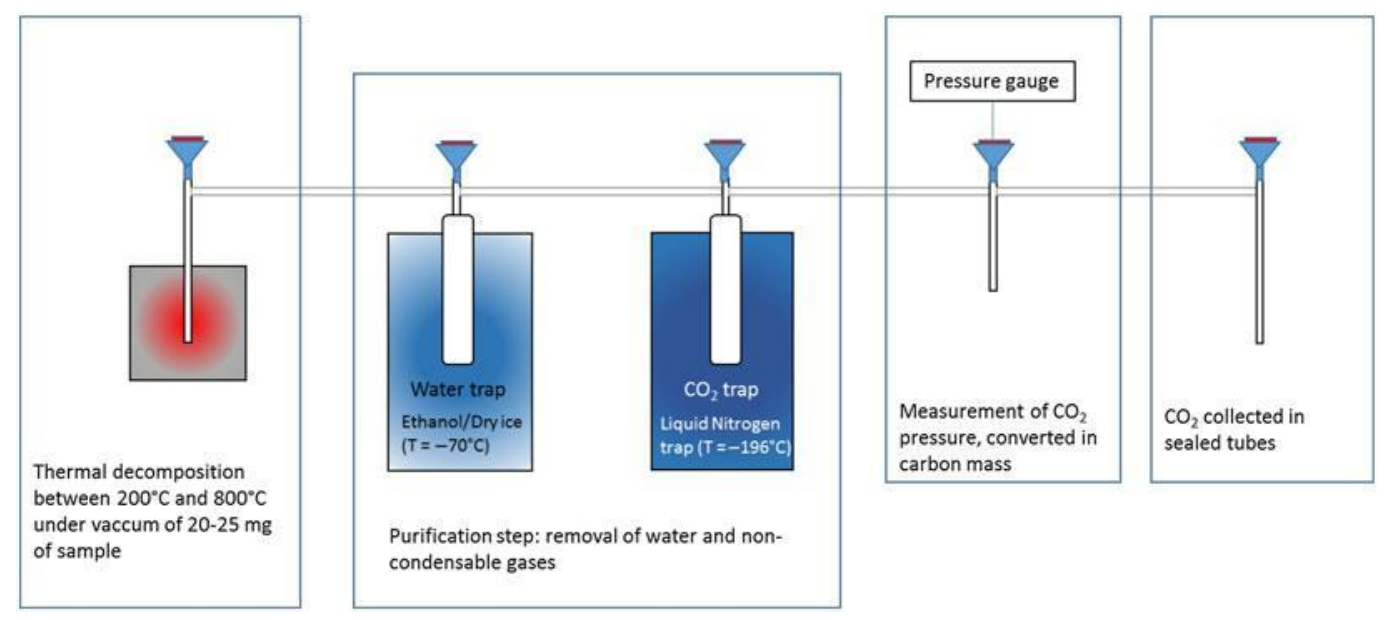

Figure $1 \quad \mathrm{CO}_{2}$ collection line for lead carbonate preparation at LMC14.

historical samples. The second section shows the dating results. All the data are reported in Table 2 .

Sample Preparation: Carbon Extraction by Thermal Decomposition

\section{Pure Lead White}

Total $\mathrm{CO}_{2}$ released after heating of $20 \mathrm{mg}$ of lead white (samples MM) for $2 \mathrm{hr}$ was collected for each temperature. Figure $2 \mathrm{a}$ reports the total carbon content obtained as a function of the temperature. At $200,250,300,350$, and $400^{\circ} \mathrm{C}$, the amount of collected carbon was $0.1,0.9,2.9$, 3.2 and $4.4 \%$. The values from 0.1 to $3.2 \%$ correspond to the $\mathrm{CO}_{2}$ release during the first steps of decomposition. At low temperatures, lead white was partially decomposed and two intermediate oxy-carbonates $\mathrm{PbCO}_{3} \cdot \mathrm{PbO}$ and $\mathrm{PbCO}_{3} \cdot 2 \mathrm{PbO}$ were obtained according to Equations (1) and (2):

$$
\begin{gathered}
2 \mathrm{PbCO}_{3} ! \mathrm{PbCO}_{3} \cdot \mathrm{PbO} \mathrm{CO}_{2} \\
3 \mathrm{PbCO}_{3} \cdot \mathrm{PbO} ! 2 \mathrm{PbCO}_{3} \cdot 2 \mathrm{PbOCO}_{2}
\end{gathered}
$$

At $400^{\circ} \mathrm{C}$, the collected carbon content reached the value of $4.44 \%$, which is close to the carbon content in $\mathrm{PbCO}_{3}$ (4.49)\%. This value was constant for temperatures between 400 and $700^{\circ} \mathrm{C}$, indicating that the $\mathrm{CO}_{2}$ release was complete. At these temperatures, the final dissociation of the oxy-carbonate forms lead monoxide (Equation 3).

$$
\mathrm{PbCO}_{3} \cdot 2 \mathrm{PbO} ! 3 \mathrm{PbO} \mathrm{CO}_{2}
$$

The formation of $\mathrm{PbO}$ was indicated by the reddish and yellow colors of the combustion residues, characteristic of massicot (orthorhombic PbO) (Figure 2c) and confirmed by XPS (Figure 3).

The total decomposition reaction can be summarized by: $\mathrm{PbCO}_{3} \rightarrow \mathrm{PbO}+\mathrm{CO}_{2}$. At $400^{\circ} \mathrm{C}$, we can consider that the total recovery of $\mathrm{CO}_{2}$ means that the total original content of carbon contained in $\mathrm{PbCO}_{3}$ has been collected. At higher temperature $\left(800^{\circ} \mathrm{C}\right)$, the residue melts as 
Table 2 Extracted carbon content, carbon mass, pMC, and ${ }^{14} \mathrm{C}$ dating results of modern lead white pigments and historical samples of cosmetic and paintings. Results on leather supports are indicated for comparison.

\begin{tabular}{|c|c|c|c|c|c|c|c|c|}
\hline $\begin{array}{l}\text { Label and } \\
\text { preparation } \\
\text { temp. }\left({ }^{\circ} \mathrm{C}\right)\end{array}$ & Material & $\begin{array}{l}\text { Date of } \\
\text { production or } \\
\text { expected age }\end{array}$ & $\begin{array}{l}\% \text { carbon } \\
( \pm 0.10 \%)\end{array}$ & $\begin{array}{c}\mathrm{C} \text { mass } \\
(\mathrm{mg})\end{array}$ & $\mathrm{pMC}$ & $\begin{array}{c}{ }^{14} \mathrm{C} \\
\text { date } \pm 30 \\
(\text { years BP) }\end{array}$ & $\begin{array}{c}\text { Calibrated date } \\
\text { (years cal BC/AD; } \\
95.4 \% \text { ) }\end{array}$ & Lab number \\
\hline MM-400 & Lead white & End of 2015 & 4.39 & 1.10 & $102.2 \pm 0.2$ & & $1955-1956 \& 2013-2016$ & SacA49833 \\
\hline MM-500 & pigment & & 4.35 & 1.10 & $101.8 \pm 0.2$ & & & SacA49834 \\
\hline MM-600 & & & 4.43 & 1.10 & $101.5 \pm 0.2$ & & & SacA52819 \\
\hline MM-700 & & & 4.44 & 1.14 & $101.8 \pm 0.2$ & & & SacA52820 \\
\hline $\mathrm{MM}+\mathrm{C} 400$ & Lead white & Modern & 4.34 & 1.10 & $102.4 \pm 0.2$ & & $1955-1956 \& 2013-2016$ & SacA49838 \\
\hline $\mathrm{MM}+\mathrm{C} 700$ & $\begin{array}{l}\text { pigment and } \\
\text { calcite in powder }\end{array}$ & & 7.69 & 1.94 & $58.8 \pm 0.2$ & & & SacA49843 \\
\hline $\mathrm{MM}+\mathrm{O} 400$ & Paint & Modern & 4.54 & 1.32 & $102.2 \pm 0.5$ & & $1955-1956 \& 2013-2016$ & SacA52825 \\
\hline MH 400 & $\begin{array}{l}\text { Lead white } \\
\text { pigment }\end{array}$ & 2016 & 3.40 & 0.71 & $103.0 \pm 0.3$ & & $1955-1956 \& 2012-2016$ & SacA51769 \\
\hline GC 400 & Compact powder & 4 th-3rd c. BC & 3.35 & 1.08 & $76.6 \pm 0.2$ & 2140 & $353-57$ & $\begin{array}{l}\text { SacA48856 } \\
\text { (Becket al. } \\
\text { 2018) }\end{array}$ \\
\hline \multirow[t]{2}{*}{ GL1 400} & \multirow{2}{*}{$\begin{array}{l}\text { Lead white paint } \\
\text { layer }\end{array}$} & \multirow{2}{*}{$\begin{array}{l}\text { Second half of } \\
\text { the } 17 \text { th }\end{array}$} & \multirow[t]{2}{*}{2.4} & 0.54 & $96.57 \pm 0.22$ & 280 & $1498-1795$ & SacA52814 \\
\hline & & & & 0.41 & $96.62 \pm 0.20$ & 275 & $1514-1798$ & SacA54660 \\
\hline GL1 & Leather & century & & & $97.34 \pm 0.34$ & 215 & 1644-:: : & SacA52830 \\
\hline \multirow[t]{2}{*}{ GL2 400} & Lead white paint & Before 1736 & 3.0 & 0.54 & $97.42 \pm 0.22$ & 210 & $1646-:::$ & SacA52813 \\
\hline & layer & & & 0.50 & $97.60 \pm 0.22$ & 195 & $1648-:::$ & SacA54661 \\
\hline GL2 & Leather & & & & $98.08 \pm 0.24$ & 155 & 1666-:: : & SacA52829 \\
\hline
\end{tabular}


C

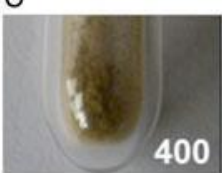

400
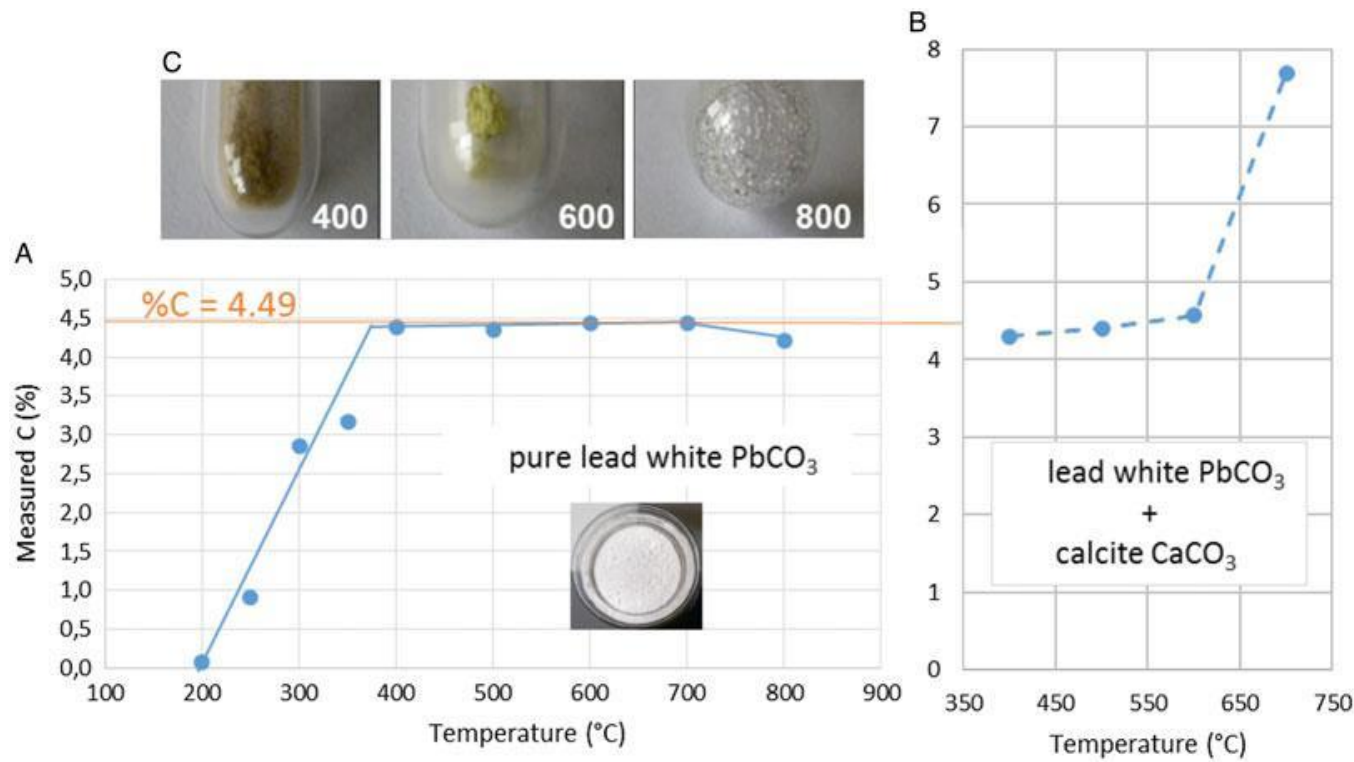

Figure 2 Total amount of carbon released (in absolute percentage with $\pm 0.1 \%$ uncertainty) from A) pure lead white (sample MM) and B) a mixture of lead white with calcite (sample $\mathrm{MM}+\mathrm{C}$ ) as a function of the heating temperature. C) From left to right: residues after decomposition at 400,600 , and $800^{\circ} \mathrm{C}$

$-\mathrm{PbCO}_{3}$

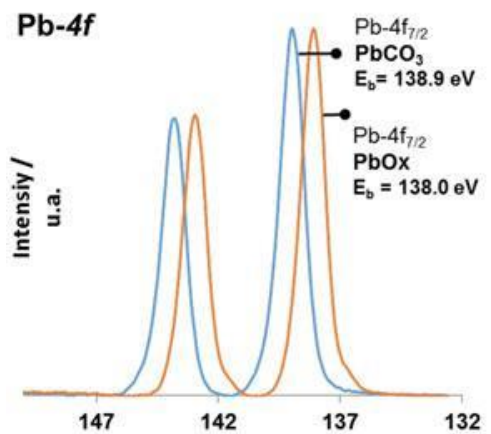

C-1s

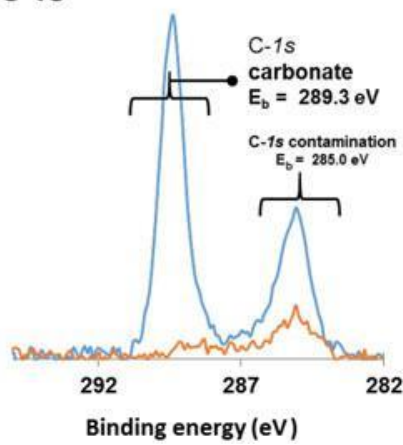

$0-1 s$

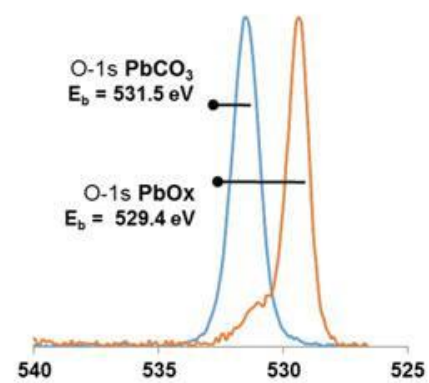

Figure $3 \mathrm{~Pb}-4 \mathrm{f}, \mathrm{C}-1 \mathrm{~s}$, and O-1 s XPS spectra of lead white before (in blue) and after heating (in orange), showing the vanishing of the carbonate structure and the formation of lead oxide (color images online).

observed in Figure 2c. Decomposition experiments were also conducted for $1 \mathrm{hr}$, leading to the same results.

\section{Mixed Carbonates: Lead White and Calcite}

As all carbonates undergo thermal decomposition to give the metal oxide and carbon dioxide gas, we also investigated the decomposition of mixtures of lead white and calcite between 400 and $700^{\circ} \mathrm{C}$ (Figure $2 \mathrm{~b}$ ). At 400 and $500^{\circ} \mathrm{C}$, the percentage of carbon collected was close to 
$4.49 \%$ corresponding to the $\mathrm{CO}_{2}$ released by the lead carbonate. At higher temperatures, the content of collected carbon strongly increased, indicating that from $600^{\circ} \mathrm{C}$, calcite partially decomposes producing also $\mathrm{CO}_{2}$. This contamination in dead carbon must be avoided in order to obtain reliable results from lead white. As a result, we selected the temperature of $400^{\circ} \mathrm{C}$ as the best condition to optimize the $\mathrm{CO}_{2}$ production yield and to collect $\mathrm{CO}_{2}$ from lead carbonate only. The choice of this condition was confirmed by heating pure calcite at 400 and $500^{\circ} \mathrm{C}$ : no release of $\mathrm{CO}_{2}$ was observed. For future experiments, we plan to implement a two-step procedure to assess the efficiency of the selective separation of lead white and chalk to obtain age determinations for each subsample.

\section{Paint: Lead White and Linseed Oil}

The decomposition of the paint was carried out at 400 and $500^{\circ} \mathrm{C}$. The percentages of carbon collected were $4.54 \%$ and $4.7 \%$, respectively. These values are slightly above $4.49 \%$ due to the contribution of the oil. As the linseed oil is generally produced in the same period of time as the pigment, we assume that the contamination by the binder will not significantly alter the dating results.

\section{Test Sample, Ancient Cosmetic and Paintings}

The decomposition of the pigment $(\mathrm{MH})$, the cosmetic powder (GC) and the painting samples (GL) was carried out at $400^{\circ} \mathrm{C}$. The collected carbon contents were between 2.4 and $3 \%$ (Table 2) due to the presence of hydrocerussite $(\% \mathrm{C}=3.1 \%)$.

\section{${ }^{14} \mathrm{C}$ Measurements}

The results of the ${ }^{14} \mathrm{C}$ measurements are reported in Table 2, in pMC for the modern samples and in years BP for the historical samples. For the modern pigments, we obtained pMC values from $101.5 \pm 0.2$ to $103.0 \pm 0.3$, except for the sample MM mixed with calcite and decomposed at $700^{\circ} \mathrm{C}(58.8 \pm 0.2 \mathrm{pMC})$. The high $\mathrm{pMC}$ values are in agreement with the dates of the pigment production in 2015-2016. The low pMC value is due to dead carbon contamination since at this temperature, we observed that calcite starts to decompose. These results confirm that the preparation of lead white must be carried out at $400^{\circ} \mathrm{C}$ to prevent any contamination from calcite decomposition. The presence of oil (sample MM+O) did not affect the result (102.2 $\pm 0.5 \mathrm{pMC}$ ), indicating that the linseed oil was also produced recently.

The Greek cosmetic sample (GC), composed of pure cerussite, was preserved in a small box found in a tomb discovered in Eretria (Greece). This tomb was dated on a numismatic basis from ca. 330 to ca. 266 BC (Hasselin Rous and Huguenot 2017). Two previous ${ }^{14} \mathrm{C}$ dates measured on an almond seed were also available: $359-112$ calBC and 375-203 calBC (Gandolfo and Richardin 2011). The dating of the cerussite powder gives a date range of 353 to $57 \mathrm{BC}(95.4 \%)$ (Table 2). This date is in agreement with the numismatic result and consistent with the almond seed results as shown by a chi squared test value of $\mathrm{T}=3.7<6$ published in Becket al. (2018).

The two samples of paint layers come from decorated leathers which were used to cover walls. The leather was first gilt with silver leaves and then partially painted. Two specimens painted with lead white were taken at the surface of the leather fragments. According to the historical or stylistic information, the gilt leather \#1 dates from the second half of the 17 th century and the gilt leather \#2 was mentioned in a castle record in 1736. 


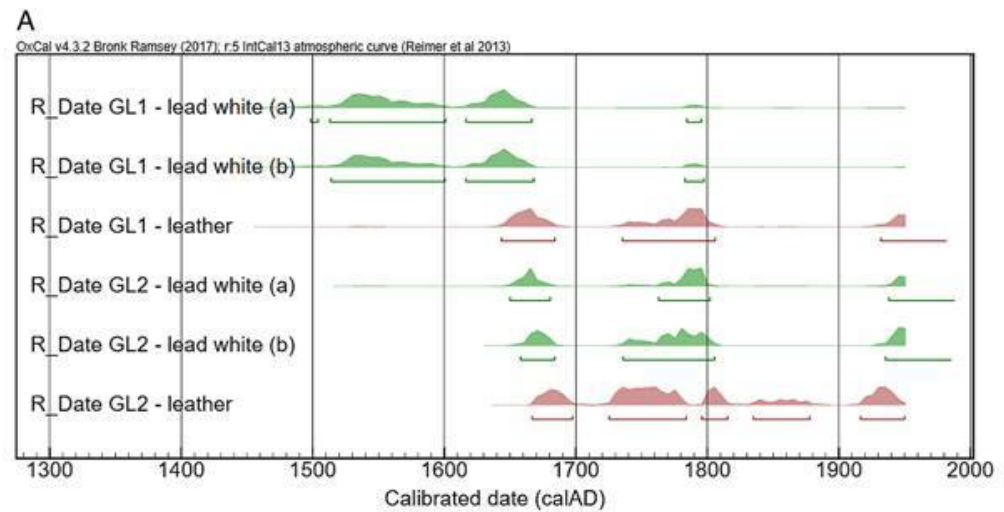

B

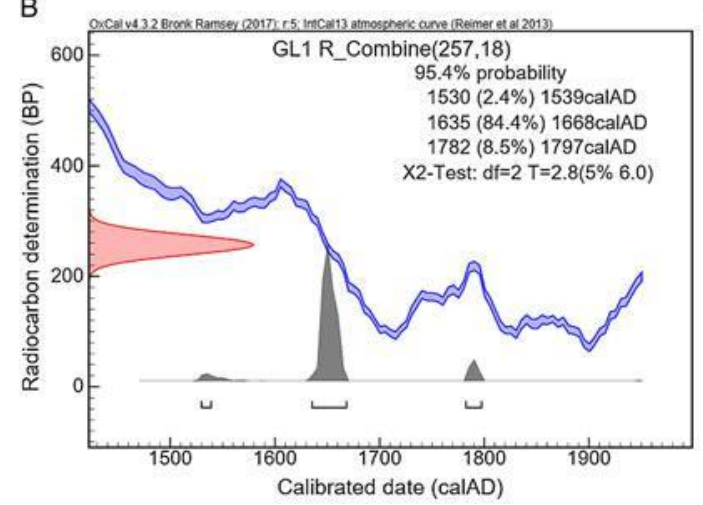

C

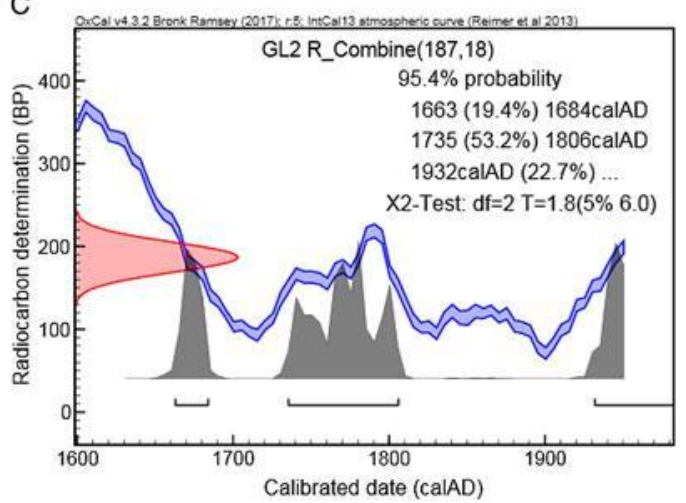

Figure 4 Dating results of the gilt leathers 1 and 2: A) comparison of the age distribution of the leather (in red) and two lead white samples taken from the paint layer (in green); B) and C) combination of the three age distributions obtained on GL1 and GL2. (Please see electronic version for color figures.)

The results on the lead whites and the leathers are reported in Table 2 and compared after calibration in Figure 4a. We can observe a very good agreement between the paint layer dates and the leather date for GL2 but to a lesser extent for GL1. However, the consi stency of the dates is demonstrated in both cases by the chi squared test values ( $\mathrm{T}=2.8<5$ for GL1 and $\mathrm{T}=4.4<5$ for GL2). Regarding GL1, manufacture of the lead white pigment earlier than the animal death cannot be excluded.

The dates are also in agreement with the historical information. For GL1, the most probable range of dates (1635-1668 [84.4\%]; Figure 4b) is very close to the expected time of its manufacture in the second half of the 17th century. For GL2, due to the fluctuations of the calibration curve, we obtained a large probability distribution. The first interval (1663-1684; Figure 4c) fits with the historical record mentioning that the decor was already in place in 1736 . This information makes it possible to exclude the latest dates and suggests that the leather was decorated and painted at the end of the 17 th century.

Despite the fluctuations of the calibration curves, we obtained ${ }^{14} \mathrm{C}$ measurements in agreement with the expected dates for modern samples as well as for historical specimens of lead white, whatever the composition (cerussite/hydocerussite) and the time scale. These results validate 
the preparation protocol based on thermal decomposition for producing $\mathrm{CO}_{2}$. They also confirm that lead white incorporates ${ }^{14} \mathrm{C}$ during its manufacture.

\section{CONCLUSION}

The possibility of ${ }^{14} \mathrm{C}$ dating lead white pigment has been investigated. The preparation protocol based on the thermal decomposition of lead carbonates was characterized by SEM, XRD and XPS. A decomposition temperature of $400^{\circ} \mathrm{C}$ was determined to extract $\mathrm{CO}_{2}$ from lead white and to prevent contamination by other carbonates such as calcite. This selective process is necessary as adulteration of lead white with chalk was often reported in the past to reduce the cost of the paints (Stols-Witlox 2011). For future experiments, we plan to implement a systematic two-step thermal procedure to check the efficiency of the selective separation and obtain age determinations for each subsample of lead white and chalk.

Successful ${ }^{14} \mathrm{C}$ measurements of modern and historical lead whites have been obtained. An ancient Greek cosmetic powder and two samples taken from paint layers of the 17 th century have been dated and the results are in agreement with the expected ages. The results confirm our experimental approach and further validate the assumption that ${ }^{14} \mathrm{C}$ dating of lead white can be based on the principle of the incorporation of ${ }^{14} \mathrm{C}$ when its synthesis uses organic reagents. This study demonstrates that paintings can be dated by dating the lead white pigment in addition to the binder and support (canvas or wood). Support ages can be subjected to discussion regarding possible reuse and the binder can be contaminated by varnish or later restorations. Combining ${ }^{14} \mathrm{C}$ dating of these three components—-pigment, binder, support—may provide a more reliable age for the paintings and stronger evidence for their authentication.

\section{ACKNOWLEDGMENTS}

The authors thank P. Bonnaillie (CEA/DEN/DMN/SRMP) for SEM experiments presented in the supplementary material section. This is LSCE contribution no. 6502.

\section{SUPPLEMENTARY MATERIAL}

To view supplementary material for this RDC.2019.64

article, please visit https://doi.org/10.1017/

\section{REFERENCES}

Ball MC, Casson MJ. 1975. Thermal studies on lead (II) salts-I. Stoicheiometry of lead carbonate decomposition at 1 atm. pressure. Journal of Inorganic Nuclear Chemistry 37:2253-2255.

Beck CW. 1950. Differential thermal analysis curves of carbonate minerals. American Minerologist 35:985-1013.

Beck L, de Viguerie L, Walter P, et al. 2010. New approaches for investigating paintings by ion beam techniques. Nuclear Instruments and Methods in Physics Research B 268:2086-2091.

Beck L, Caffy I, Delqué-Kolic E, Moreau C, Dumoulin JP, Perron M, Guichard H, Jeammet V. 2018. Absolute dating of lead carbonates in ancient cosmetics by radiocarbon.
Communications Chemistry 1(34):1-7. doi: 10 . 1038/s42004-018-0034-y.

Bonnot-Diconne C, Robinet L, Pacheco C, Iole M, Paris M. 2014. Multi-technique analysis of giltleather wall coverings (16th-18th centuries). ICOM-CC 17th Triennial Conference preprints. Melbourne. 15-19 September 2014. Paris: International Council of Museums.

Brock F, Eastaugh N, Ford T, Townsend JH. 2018. Bomb-pulse radiocarbon dating of modern paintings on canvas. Radiocarbon 60(1):1-11.

Bronk Ramsey C, Scott M, van der Plicht J. 2013. Calibration for archaeological and environmental terrestrial samples in the time range $26-50 \mathrm{ka}$ cal BP. Radiocarbon 55:2021-2027. 
Caforio L, Fedi M, Liccioli L, Salvini A. 2013. The issue of contamination by synthetic resins in radiocarbon dating: the case of a painting by Ambrogio Lorenzetti. Procedia Chemistry 8: 2834.

Ciomartan DA, Clark RJH, McDonald LJ, Odlyha M. 1996. Studies on the thermal decomposition of basic lead(II) carbonate by Fourier transform Raman spectroscopy, X-ray diffraction and thermal analysis. Journal of the Chemical Society, Dalton Transactions 18:3639-3645.

de Viguerie L, Beck L, Salomon J, et al. 2009. Composition of Renaissance paint layers: simultaneous particle induced $\mathrm{x}$-ray emission and backscattering spectrometry. Analytical Chemistry 81:7960-7966.

Dumoulin JP, Comby-Zerbino C, Delqué-Kolic E, Moreau C, Caffy I, Hain S, Perron M, Thellier B, Setti V, Berthier B, Beck L. 2017. Status report on sample preparation protocols developed at the LMC14 Laboratory, Saclay, France: from sample collection to ${ }^{14} \mathrm{C}$ AMS measurement. Radiocarbon 59:713-726.

Fedi ME, Caforio L, Liccioli L, Mandò PA, Salvini A, Taccetti F. 2014 A simple and effective removal procedure of synthetic resins to obtain accurate radiocarbon dates of restored artworks. Radiocarbon 56:969-979.

Gandolfo N, Richardin P. 2011. Radiocarbon dating of an almond of the Eretria city (CA 518). Report $n^{\circ}$ 21072. C2RMF. Paris: Louvre Museum.

Gettens RJ, Kühn H, Chase WT. 1993. Lead white. In: Roy A, editor. Artists' pigments: a handbook of their history and characteristics. Vol. 2. Washington (DC): National Gallery of Art. p. 6781.

Gonzalez V, Gourier D, Calligaro T, Toussaint K, Wallez G, Menu M. 2017a. Revealing the origin and history of lead-white pigments by their photoluminescence properties. Analytical Chemistry 89:2909-2918.

Gonzalez V, Wallez G, Calligaro T, Cotte M, de Nolf W, Eveno M, Ravaud E, Menu M. 2017b. Synchrotron-based high angle resolution and high lateral resolution X-ray diffraction reveals lead white pigment qualities in Old Masters paintings. Analytical Chemistry 89(24):13203-13211.

Hasselin Rous I, Huguenot C. 2017. Offrandes hellénistiques en miniature: le mobilier d'une tombe d'enfant d'Erétrie conservé au musée du Louvre. Revue Archéologique 63:3-64.

Hendriks L, Hajdas I, McIntyre C, Küffner M, Scherrer NC, Ferreira ESB. 2016. Microscale radiocarbon dating of paintings. Applied Physics A 122:16.

Hendriks L, Hajdas I, Ferreira ESB, Scherrer NC, Zumbühl S, Küffner M, Wacker L, Synal HA, Günther D. 2018. Combined ${ }^{14} \mathrm{C}$ analysis of canvas and organic binder for dating a painting. Radiocarbon 60(1):49-58.
Hendriks L, Hajdas I, Ferreira ESB, Scherrer NC, Zumbühl S, Küffner M, Carlyle L, Synal HA. Günther D. 2019. Selective dating of paint components: radiocarbon dating of lead white pigments. Radiocarbon 61:473-493.

Katsaros T, Liritzis I, Laskaris N. 2010. Identification of Theophrastus' pigments egyptios yanos and psimythion from archaeological excavations. ArcheoSciences 34:69-79.

Levin I, Kromer B. 2004. The tropospheric ${ }^{14} \mathrm{CO} 2$ level in mid latitudes of the Northern Hemisphere. Radiocarbon 46(3):1261-1272.

Lucas A. 1930. Cosmetics, perfumes and incense in ancient Egypt. The Journal of Egyptian Archaeology 16:41-53.

Martinetto P, Anne M, Dooryhée E, Drakopoulos M, Dubus M, Salomon J, Simonovici A, Walter P. 2001. Synchrotron X-ray micro-beam studies of ancient Egyptian make-up. Nuclear Instruments and Methods in Physics Research B 181:744-748.

Mook WG, van der Plicht J. 1999. Reporting ${ }^{14} \mathrm{C}$ activities and concentrations. Radiocarbon 41:227239.

Moreau C, Caffy I, Comby C, Delqué-Kolic E, Dumoulin JP, Hain S, Quiles A, Setti V, Souprayen C, Thellier B, Vincent J. 2013. Research and Development of the Artemis ${ }^{14} \mathrm{C}$ AMS Facility: Status Report. Radiocarbon. 55:331-337

Pedanius Dioscorides of Anazarbus. De material medica, Beck LY, translator; Beck LY, 2017. editor. 3rd revised edition. Hildesheim: Olms Verlag AG.

Pliny the Elder. 1855. The natural history. Bostock J, Riley HT, translators. London: Taylor and Francis.

Pulsifer WH. 1888. Notes for a history of lead and an inquiry into the development of the manufacture of white lead and lead oxides. New York: D Van Nostrand.

Reimer PJ, Bard E, Bayliss A, Warren Beck J, Blackwell PG, Bronk Ramsey C, Buck CE, Cheng H, Lawrence Edwards R, Friedrich M, Grootes PM, Guilders on TP, Haflidas on H, Hajdas I, Hatté C, Heaton TJ, Hoffmann DL, Hogg AG, Hughen KA, Kaiser KF, Kromer B, Manning SW, Niu M, Reimer RW, Richards DA, Marian ScottE, Southon JR, Staff

RA, Turney CSM, van der Plicht J. 2013. IntCal13 and Marine13 radiocarbon age calibration curves 0-50, 000 years cal BP. Radiocarbon 55:

1869-1887.

Stols-Witlox M. 2011. The heaviest and the whitest: lead white quality in north western European documentary sources, 1400-1900. In: Spring M, editor. Studying Old Master paintings- technology and practice. London: Archetype Publications. p. 284-294.

Stols-Witlox M. 2014. Historical recipes for preparatory layers for oil paintings in manuals, manuscripts and handbook in North West 
Europe, 1550-1900: analysis and recon-structions 1400-1900 [PhD thesis]. University of Amsterdam.

Theophrastus. 1956. Liber de lapidibus. In: Caley ER, Richards JFC, editors. Theophrastus on stones. Introduction. Columbus $(\mathrm{OH})$ : Ohio State University Press. Greek text with English translation and commentary.

Walter P, Martinetto P, Tsoucaris G, Bréniaux R, Lefebvre MA, Richard G, Talabot J, Dooryhee E. 1999. Making make-up in Ancient Egypt. Nature 397:483-484.
Warne SS, Bayliss P. 1962. The differential thermal analysis of cerussite. The American Mineralogist 47:1011-1023.

Welcomme E, Walter P, Van Elslande E, Tsoucaris G 2006. Investigation of white pigments used as make-up during the Greco-Roman period. Applied Physics A 83:551-556.

Welcomme E, Walter P, Bleuet P, Hodeau J-L, Dooryhee E, Martinetto P, Menu M. 2007. Classification of lead white pigments using synchrotron radiation micro X-ray diffraction. Applied Physics A 89:825-832. 